\title{
Kajian Dan Praktik Ekranisasi Cerpen Perempuan di Rumah Panggung ke Film Pendek Angkon
}

\author{
Jafar Fakhrurozi ${ }^{1 *}$, Qadhli Jafar Adrian ${ }^{2)}$ \\ jafar.fakhrurozi@teknokrat.ac.id ${ }^{1)}$, qadhliadrian@teknokrat.ac.id ${ }^{2)}$ \\ Jalan Z.A Pagar Alam No.09-11 Labuhanratu, \\ Bandarlampung
}

\begin{abstract}
Abstrak. Penelitian ini mengkaji proses pembelajaran ekranisasi dari cerpen Perempuan di Rumah Panggung ke film pendek Angkon. Proses tersebut meliputi proses penafsiran terhadap cerpen dan proses produksi film pendek. Metode yang digunakan adalah kulitatif deskriptif. Sementara untuk analisis ekranisasi menggunakan teori ekranisasi, transformasi, dan alih wahana. Hasil penelitian menunjukkan bahwa terjadi pengurangan, penambahan, dan perubahan variasi yang terjadi dari cerpen ke film. Perubahan terjadi pada unsur intrinsik dan ekstrinsik. Perubahan tersebut diakibatkan oleh penafsiran sineas dan demi kepentingan film yang diproduksi. Hasil lain menunjukkan bahwa proses produksi film pendek membutuhkan kerja kolektif dan kolaboratif serta membutuhkan kompetensi khusus di bidang sinematografi
\end{abstract}

Kata kunci: Pembelajaran, Ekranisasi, Cerpen, Film Pendek, Transformasi, Pengurangan, Penambahan, Perubahan Variasi

\section{Pendahuluan}

Kegiatan ekranisasi sudah banyak dilakukan di Indonesia. Sebagian besar karya yang di ekranisasi adalah novel. Hal ini dapat dimaklumi mengingat karakteristik novel yang kompleks dan dapat dijadikan sebagai representasi kehidupan masyarakat. Namun demikian, karya sastra lain juga dapat diekranisasi ke dalam film.

Sejumlah film yang ceritanya bersumber dari karya sastra sudah mulai diproduksi sejak tahun 1920-an. Dalam catatan Christopher Woodrich, pada 1926 terdapat satu film yang ceritanya diangkat dari karya sastra dalam hal ini cerita rakyat yakni film Loetoeng Kasaroeng karya L. Heuveldorp. Selanjutnya pada era kolonialisme yaitu pada 1927, juga telah diproduksi film yang berasal dari novel dengan judul Eulis Atjih karya George Krugers. Pada era orde lama, terdapat dua film yang diangkat berdasarkan naskah drama yakni Tjitra karya Usmar Ismail pada 1949 dan Film Dr Samsi karya Ratna Asmara (1952).

Selain itu pada tahun 1949 telah diproduksi film yang diangkat dari cerita pendek (cerpen) dengan judul Harta Karun karya Usmar Ismail. Pada masa orde baru, yakni tahun 1982 juga diproduksi satu film yang berasal dari cerita rakyat dengan judul Sangkuriang karya Sisworo Gautama Putra.

Setelah era orde baru yakni awal tahun 2000-an, film-film yang diproduksi hasil ekranisasi dapat dibilang sebagai masa produktif. Film-film hasil adaptasi novel ke film menjamur di bioskop. Hingga tahun 2017, ada 42 judul novel yang diangkat menjadi film (Praharwati dkk., 2017). Film-film tersebut dikenal dengan istilah ekranisasi.

Dalam catatan Istadiyantha dan Rianna Wati (2015), film hasil ekranisasi semakin diterima masyarakat setelah film Ayat-ayat Cinta pada tahun 2008. Film Ayat-ayat Cinta adalah salah satu 
fenomena adaptasi yang banyak menyedot perhatian masyarakat luas segala kalangan dan usia. Film Ayat-ayat Cinta memecahkan rekor sebagai film yang banyak ditonton orang di bioskop, mengungguli film Ada Apa dengan Cinta pada tahun 2002. Setelah itu rilis film Perempuan Berkalung Sorban (2008), Ketika Cinta Bertasbih (2009), Laskar Pelangi (2009), Sang Pemimpi (2010), Sang Penari (2010), Surat Kecil untuk Tuhan (2011), Di Bawah Lindungan Ka'bah (2011), Negeri Lima Menara (2012) dan sebagainya.

Selain ekranisasi dari novel, rilis juga film-film yang diangkat dari cerita pendek (cerpen). Misalnya film Tentang Dia (2005), Mereka Bilang Saya Monyet (2008), Emak Ingin Naik Haji (2009), dan Rumah Tanpa Jendela (2010).

Dalam pembelajaran sastra, ekranisasi merupakan salah satu bentuk pembelajaran alih wahana. Alih wahana merupakan peralihan bentuk karya satu ke bentuk karya yang lain, sedangkan ekranisasi dikhususkan pada peralihan novel ke dalam bentuk film. Suseno dalam Faidah (2019:6) menyatakan bahwa ada beberapa teori yang dapat dipetakan kekerabatannya dengan teori ekranisasi, yaitu teori alih wahana oleh Damono, teori adaptasi Hutcheon, dan teori resepsi oleh Iser.

Keberadaan film ekranisasi dari cerpen dapat dijadikan sebagai bahan pembelajaran sastra di perguruan tinggi. Dengan banyaknya film ekranisasi, pembelajaran sastra terutama pembelajaran apresiasi sastra dapat lebih ditingkatkan. Film hasil ekranisasi dapat dijadikan sebagai bahan dan media pembelajaran yang menarik bagi mahasiswa. (Fakhrurozi, 2020).

Pada praktiknya keberadaan film ekranisasi tidak banyak melibatkan mahasiswa dalam proses produksinya, padahal proses pembelajaran akan lebih mengena bila mahasiswa terlibat dari mulai pemilihan cerpen, penyusunan naskah film, hingga pembuatan film. Mahasiswa lebih dapat memahami unsur-unsur intrinsik/ekstrinsik yang ada dalam cerpen. Menurut Aniskurli (2020), pemahaman peserta didik terhadap unsur-unsur intrinsik karya sastra dalam film dapat diimplikasikan dalam pembelajaran sastra khususnya pembelajaran ekranisasi yang lebih spesifik berkaitan dengan pembelajaran alur dan tokoh/penokohan. Selain kompetensi bidang sastra, pembelajaran ekranisasi dapat memberikan pengetahuan tambahan kepada mahasiswa tentang sinematografi.

Namun demikian, karena sifatnya kolaboratif antara sastra dan film, pembelajaran ekranisasi menjadi pembelajaran alternatif bagai mahasiswa sastra terutama bagi mahasiswa yang menyukai sastra populer.

Penelitian tentang ekranisasi dari cerita pendek ke film telah banyak dilakukan. Namun demikian, penelitian yang berkaitan dengan pembelajaran sastra belum banyak dilakukan. Citra Nur Faidah dalam penelitian yang berjudul "Ekranisasi Sastra sebagai Bentuk Apresiasi Sastra Penikmat Alih Wahana" (2019) merupakan salah satu penelitian yang paling reevan dengan topik ini. Penelitian tersebut menjelaskan tentang problematika apresiasi penikmat sastra terhadap karya hasil ekranisasi. Disebutkan dalam penelitian bahwa terdapat respons negatif dan positif dari pengarang dan apresiator. Respons negatif menunjukkan bahwa pengarang dan penonton merasa tidak puas atau kecewa terhadap hasil ekranisasi. Sebagaimana dijelaskan Eneste (1997) bahwa kekecewaan pengarang tecermin dari tidak terungkapnya nilai sastra yang terkandung dalam karya aslinya, menyimpangnya dari karya asli, dan kurangnya penyampaian amanat dari karya asli. Kekecewaan penonton tecermin dari cerita, jalan cerita, maupun karakter tokoh yang dinilai 
berbeda dari karya aslinya. Untuk mengatasi hal tersebut penulis memberikan rekomendasi di antaranya agar ada proses pendekatan antara penulis novel dengan produser film. Pendekatan ini bertujuan untuk menjalin kerja sama antara penulis dalam proses pembuatan film, mulai dari pembuatan naskah, casting, hingga pengambilan gambar per adegan. Kerja sama seperti ini dapat memilih dan mempertahankan adegan esensial dalam cerita yang diangkat ke dalam film.

Selain itu, upaya lain untuk mengatasi kekecewaan yang mungkin muncul adalah dengan memproduksi film sendiri. Menurut Rosa dalam Faidah (2019), memproduksi film sendiri dapat dengan bebas menentukan filmisasi novel. Bebas dalam arti dapat membuat, memilih, serta mempertahankan adegan yang diinginkan. Pembuatan film sendiri dapat dilaukan tanpa mengeluarkan biaya yang besar, dalam kata lain biaya tidak dikeluarkan oleh produser, melainkan diperoleh melalui usaha-usaha dan sumber lain. (Rosa dalam Faidah, 2019).

Penelitian lainnya lebih banyak mengemukakan tentang kajian ekranisasi dari cerpen ke film. Seperti yang dilakukan oleh Dimas Estyaji dengan judul "Ekranisasi Cerpen Filosofi Kopi dalam Kumpulan Cerpen Filosofi Kopi karya Dewi Lestari ke Dalam Film Filosofi Kopi Sutradara Angga Dwimas Sasongko". Penelitian ini menjelaskan tentang transformasi dalam bentuk kategorisasi aspek penciutan, penambahan, perubahan bervariasi dan juga perubahan alur dalam ekranisasi Cerpen ke bentuk Film "Filosofi Kopi"karya Dewi Lestari dan Angga Dwimas Sasongko.(2017).

Penelitian serupa dilakukan Suseno yang berjudul "Filmisasi Karya Sastra Indonesia: Kajian Ekranisasi pada Cerpen dan Film "Tentang Dia.". Penelitian tersebut membahas tentang transformasi yang telah menghasilkan perubahan-perubahan dalam isi cerita. (2011).Penelitian lain berjudul "Ekranisasi Cerpen "Jendela Rara" ke Film Rumah Tanpa Jendela: Kajian Psikologi Anak". Penelitian ini mengidentifikasikan dan mendeskripsikan bagaimana keterkaitan unsurunsur ekranisasi, struktural, dan psikologi anak yang terdapat dalam cerpen "Jendela Rara" dan film Rumah Tanpa Jendela". Berbeda dengan penelian sebelumnya, hasil penelitian ini menunjukkan bahwa ada perbedaan media yang digunakan antara cerpen dengan film, sehingga film yang diadaptasi dari cerpen tersebut menjadi karya tersendiri dan lahir sebagai teks baru yang tidak harus sama persis dengan cerpen sebagai hipogramnnya. (Maghfiroh dkk, 2013).

Berdasarkan penjelasan di atas, peneliti ingin mengkaji tentang proses ekranisasi yang diangkat dari cerpen sekaligus melakukan produksi film sendiri. Film yang diproduksi adalah film pendek youtube. Dari karakteristiknya antara cerpen dan film pendek lebih memiliki kesamaan, yakni sama-sama memiliki durasi yang pendek. Pertanyaan yang dapat diajukan adalah bagaimana proses produksi film dan hasil dari ekranisasi yang dilakukan?

\section{Metode}

Metode yang digunakan dalam penelitian ini adalah metode kualitatif deskriptif. Dalam penelitian ini yang dikaji adalah teks dan media audio visual. Sesuai dengan pendapat Moleong (2010) bahwa metode deskriptif adalah pengambilan data yang dilakukan melalui kata-kata, gambar, dan bukan angka-angka.

Sementara untuk proses pembuatan film, penulis menggunakan metode pembelajaran kolaboratif. Joyce \& Weil dalam Suratno (2013) mengemukakan bahwa pola pembelajaran kolaboratif dalam implementasinya memerlukan tahapan kegiatan yaitu: Penyampaian tujuan 
dan memotivasi mahasiswa; penyajian informasi dalam bentuk demonstrasi atau melalui bahan bacaan; pengorganisasian mahasiswa ke dalam kelompok-kelompok belajar; membimbing kelompok bekerja dan belajar; asesmen tentang apa yang sudah dipelajari sehingga masingmasing kelompok mempresentasikan hasil kerjanya; dan memberikan penghargaan baik secara kelompok maupun individu.

Berdasarkan tahapan tersebut, peneliti membuat tahapan pembelajaran ekranisasi di kelas Mata Kuliah Bahasa Indonesia untuk Penulisan Akademik dan Populer. Tahapan yang dilakukan adalah pembentukan kelompok, pemilihan cerpen yang akan dijadikan objek ekranisasi, dan pembuatan skenario.

Sumber data penelitian ini adalah cerpen Perempuan di Rumah Panggung karya Isbedy Stiawan ZS dan film pendek Angkon karya sutradara Yuriko yang merupakan salah satu perwakilan mahasiswa. Cerpen Perempuan Panggung diterbitkan Siger Publisher tahun 2013 di Bandarlampung. Sementara Film Angkon diproduksi tahun 2013 dengan durasi 11 menit.

\section{Hasil dan Pembahasan}

Proses ekranisasi pada dasarnya adalah proses adaptasi dari karya sastra berbentuk cerita ke media film. Proses adaptasi tersebut melahirkan beberapa perbedaan. Hal itu terjadi karena dua hal yaitu perbedaan media dan perbedaan yang lahir dari proses penafsiran. Linda Seger dalam The Art of Adaptation Turning Fact and Fiction into Film, menjelaskan bahwa adaptasi adalah sebuah proses transisi, pengubahan atau konversi dari satu medium ke medium lain (Seger dalam Ardianto, 2014). Akibat proses tersebut hasil adaptasi tentu saja akan berbeda dengan bentuk aslinya.

Namun demikian, menurut Ardianto (2014), meskipun ada perubahan, roh dari teks asli diharapkan tetap hadir dalam karya baru tersebut. Konsep adaptasi menurut Seger meliputi proses rethinking (berpikir ulang), reconceptualizing (mengkonsep ulang), dan understanding (pengertian) terhadap teks asli.

Terkait penafsiran, hal ini diutarakan oleh Linda Hutcheon dalam bukunya The Theory of Adaptation. Menurut Hutcheon (2006) adaptasi adalah sebuah cara untuk menuliskan kembali cerita yang sama tapi dengan sudut pandang yang berbeda. Hal itu merupakan efek dari proses intertekstualitas atau proses resepsi.

Proses resepsi tersebut melahirkan teks yang melekat pada memori kita yang bukan (langsung) berasal dari sumber asli melainkan berasal dari karya-karya (dalam bentuk) lain, melalui pengulangan-pengulangan yang bervariasi.

Secara gamblang model ekranisasi dijelaskan oleh Pamusuk Eneste. Menurut Eneste dalam Kurniawan (2017) perubahan yang terjadi dalam ekranisasi adalah pengurangan, penambahan, dan perubahan variasi.

\section{Pengurangan}

Menurut Eneste (1991) pengurangan yaitu pemotongan unsur cerita karya sastra dalam proses transformasi. Pengurangan dapat dilakukan terhadap unsur-unsur karya sastra seperti cerita, alur, tokoh, latar, maupun suasana. Dengan adanya proses pengurangan atau pemotongan 
maka tidak semua hal yang diungkapkan dalam novel akan dijumpai pula dalam film. Salah satu langkah yang ditempuh dalam proses transformasi sastra ke film adalah penciutan. Penciutan adalah pengurangan atau pemotongan unsur cerita dalam sastra dalam proses transformasi. Menurut Suseno (2011) pengurangan atau penciutan dapat dilakukan terhadap unsur sastra seperti cerita, alur, tokoh, latar, maupun suasana. Dengan proses penciutan tidak semua hal yang diungkapkan dalam novel akan dijumpai pula dalam film.

Suseno (2011) menambahkan, ada beberapa alasan mengapa pembuat film melakukan penciutan. Pertama, adegan maupun tokoh tertentu dalam karya sastra tersebut tidak diperlukan atau tidak penting ditampilkan dalam film. Kedua, adanya anggapan atau alasan sineas bahwa menghadirkan unsur-unsur tersebut justru dapat mengganggu cerita di dalam film. Ketiga, adanya keterbatasan teknis film atau medium film, bahwa tidak semua bagian adegan atau cerita dalam karya sastra dapat dihadirkan di dalam film. Keempat, adalah alasan penonton atau audiens, hal ini juga berkaitan dengan persoalan durasi waktu.

Dalam ekranisasi Cerpen Perempuan di Rumah Panggung ke Film Pendek Angkon, terdapat pengurangan dalam jumlah eposide. Episode cerita cerpen Perempuan di Rumah Panggung terdiri dari 29 episode cerita. Sementara di film Angkon terdapat 26 episode. Ada episode yang tidak ditampilkan dalam film yaitu episode para tokoh saat masa kanak-kanak seperti permainan tardisional gobak sodor. Hal ini diakibatkan oleh faktor keterbatasan aktor dan latar yang sesuai dengan cerpen. Pengurangan lainnya adalah pengurangan tokoh dalam film seperti tokoh orang tua yang hanya diperankan masing-masing satu yakni Rajo di pihak Ida dan Mami di pihak Imam.

\section{Penambahan dan Perubahan}

Penambahan juga dapat dilakukan dalam proses ekranisasi. Hal ini dimaksudkan untuk memperkuat cerita film. Sementara perubahan bervariasi dapat terjadi dalam ranah ide cerita, gaya penceritaan, dan sebagainya. Terjadinya variasi dalam transformasi dipengaruhi oleh beberapa faktor, antara lain media yang digunakan, persoalan penonton, durasi waktu pemutaran.

Eneste (1991:67) menyatakan bahwa dalam mengekranisasi pembuat film merasa perlu membuat variasi-variasi dalam film, sehingga terkesan film yang didasarkan atas novel itu tidak seasli novelnya. (Kurniawan, 2017). Teori ekranisasi juga berkaitan dengan teori transformasi. Menurut Nurgiantoro (2018:18), transformasi adalah perubahan yang dilakukan saat proses ekranisasi dilakukan. Perubahan dapat terjadi di tataran kata, kalimat, struktur, dan isi.

Perubahan variasi yang terdapat dalam film Angkon adalah dari segi judul, tokoh, latar, dan episode. Judul semula Perempuan di Rumah Panggung menjadi Angkon. Perubahan tersebut disinyalir untuk kepentingan praktis di mana judul Angkon lebih memiliki nilai jual daripada judul sebelumnya. Selain itu pembuat film ingin memberikan porsi lebih atau menegaskan konsep angkon yang terdapat dalam cerpen.

Perubahan lainnya terdapat pada nama-nama tokoh, di mana untuk tokoh Marni dan Pram berubah menjadi Ida dan Imam. Hal itu merupakan salah satu bentuk tafsir bahwa nama Marni dan Pram dianggap kurang relevan dengan latar adat budaya Lampung sehingga diganti dengan nama-nama bernuansa Islam sebagaimana yang biasa dijumpai di wilayah Sumatera. 
Lalu yang cukup mencolok adalah adanya pertukaran karakter antara Ida dan Imam. Dalam cerpen yang dikisahkan sekolah SMA ke kota adala Imam. Sementara dalam film, justru sebaliknya yakni tokoh Ida yang sekolah/kuliah. Perubahan tersebut dilakukan untuk mengejar aspek dramatik dalam film di mana jika dikaitkan dengan wacana feminis, tokoh perempuan saat ini dilukiskan sudah setara dengan laki-laki dan memiliki kesempatan mengakses pendidikan tinggi.

Selanjutnya perubahan pada latar yakni latar budaya. Dalam cerpen budaya yang digunakan adalah budaya Lampung Pepadun. Sementara dalam film budaya yang digunakan Lampung Pesisir/Saibatin.

Transformasi budaya tersebut diduga karena pembuat film berasal dari kultur budaya pesisir. Sehingga ada kedekatan referensi dalam penafsiran. Perubahan lainnya adalah perubahan alur. Alur dalam cerpen bersifat maju. Sementara alur film adalah alur mundur.

Perubahan selanjutnya adalah properti atau benda-benda yang digunakan. Dalam cerpen boneka yang disebutkan adalah boneka mainan dari lidi, sementara di film boneka yang digunakan adalah boneka kain.

Cerpen Perempuan di Rumah Panggung memiliki tokoh anak-anak usia sekolah. Dalam film tokoh anak-anak diperankan oleh remaja, namun demikian karakter yang diperankan tetap karakter anak-anak sebagaimana ada cerpen. Pemilihan aktor agar benar-benar sesuai dengan cerpen cukup sulit dilakukan mengingat tim yang terdiri dar mahasiswa tidak memiliki akses untuk mencari atau mengajak anak-anak kecil. Namun demikian, pemilihan aktor merupakan salah satu aspek penafsiran dalam kegiatan ekranisasi. Perubahan-perubahan tersebut dapat terjadi karena penafsiran sineas. Penafsiran yang mengakibatkan perubahan tersebut adalah hal yang wajar dana tidak dapat dikatakan sebagai penyimpangan.

\section{Pembelajaran Membuat Film Ekranisasi}

Pembelajaran membuat film pendek merupakan bagian dari pembelajaran kolaboratif. Ada beberapa tahapan sebagaimana yang telah dijelaskan pada bab sebelumnya yakni pembentukan kelompok, pemilihan cerpen yang akan dijadikan objek ekranisasi, dan pembuatan skenario dan produksi film pendek.

\section{Pembentukan Kelompok dan Pemilihan Cerpen Objek Ekranisasi}

Fase pembentukan kelompok disusun berdasarkan jumlah mahasiswa. Dari 97 mahasiswa terbentuk 9 kelompok ekranisasi. Masing-masing kelompok lalu mencari dan memilih cerpen yang akan dialihwahanakan menjadi film pendek. Film hasil ekranisasi biasanya mengangkat karya sastra yang best seller. Namun demikian, dalam pembelajaran ini peneliti memberi pertimbangan kepada mahasiswa untuk mencari cerpen yang berisi kearifan lokal. Alasan pemilihan cerpen berbasis kearifan lokal adalah untuk mengenalkan nilai-nilai lokal yang saat ini mulai tergerus zaman. Hal ini juga dilakukan untuk menyesuaikan dengan aspek sosio budaya mahasiswa yang notabene berdomisili di Provinsi Lampung. 


\section{Penulisan Skenario}

Selanjutnya, dari cerpen yang sudah dipilih mahasiswa membuat naskah film (skenario). Dalam fase ini mahasiswa diberi kebebasan untuk melakukan penafsiran terhadap cerpen untuk kemudian diubahnya menjadi naskah film pendek. Proses ini tidak berjalan mudah. Mahasiswa yang aktif berpartisipasi mulai berkurang. Hal ini wajar karena proses penafsiran dan penulisan naskah membutuhkan kompetensi khusus. Kegiatan selanjutnya adalah masuk ke dalam tahap pembuatan film pendek. Pada fase ini, peneliti hanya memilih beberapa mahasiswa dari perwakilan kelompok untuk dijadikan kelompok baru. Tujuannya adalah untuk membentuk tim pembuatan film. Skenario yang digunakan adalah salah satu skenario hasil tugas belajar sebelumnya.

Skenario yang dipilih adalah hasil adaptasi dari Cerpen Perempuan di Rumah Panggung karya Isbedy Stiawan ZS. Hasil dari pembahasan mengenai skenario film, diputuskan bahwa judul film yang akan dibuat yaitu Angkon. Pemilihan judul tersebut merupakan salah satu tafsir terhadap isi cerpen. Perubahan dalam kegiatan ekranisasi merupakan suatu hal yang lazim.

Setelah skenario dibuat, tim lalu membuat storyboard. Storyboard merupakan tampilan visual singkat bagi sebuah film. Storyboard menampilkan apakah cerita tersebut masuk akal, memiliki nilai continuity atau tidak meskipun tanpa dialog (Rudiyanto dkk., 2015).

\section{Pembuatan Film Pendek}

Tahapan berikutnya adalah praktik pembuatan film pendek. Fase ini dilakukan dengan beberapa tahapan yaitu praproduksi, produksi, dan pascaproduksi. Kegiatan praproduksi meliputi hal-hal sebagai berikut: menyeleksi kru dan menyusun tim produksi; menyeleksi aktor (casting); pencarian lokasi (setting); menyusun jadwal (scheduling) yang dibuat melalui lembar callsheet; dan membuat desain produksi (production design).

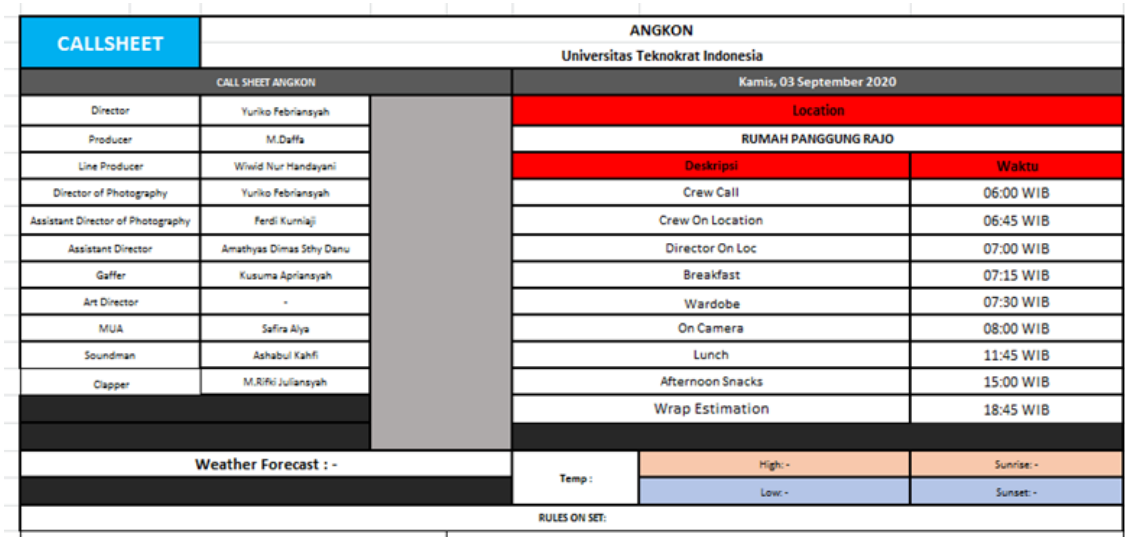

Gambar 1. Callsheet Film Angkon

Pada tahap praproduksi keterlibatan tim peneliti sangat dibutuhkan. Peneliti melakukan pendampingan sampai tim siap untuk melakukan shooting. Dalam kegiatan awal ini peneliti melibatkan mahasiswa dari jurusan lain yang memiliki kompetensi di bidang videografi dan edit film. Tahap produksi merupakan tahapan pengubahan bentuk naskah menjadi bentuk auditif dan visual sesuai dengan kaidah-kaidah yang berlaku bagi pertelevisian (Nugroho, 2007: 108). Tahap 
produksi adalah tahap eksekusi dari rencana produksi yang telah dibuat. Pada tahapan ini terjadi proses shooting dan recording untuk mengumpulkan materi visual dan audio.

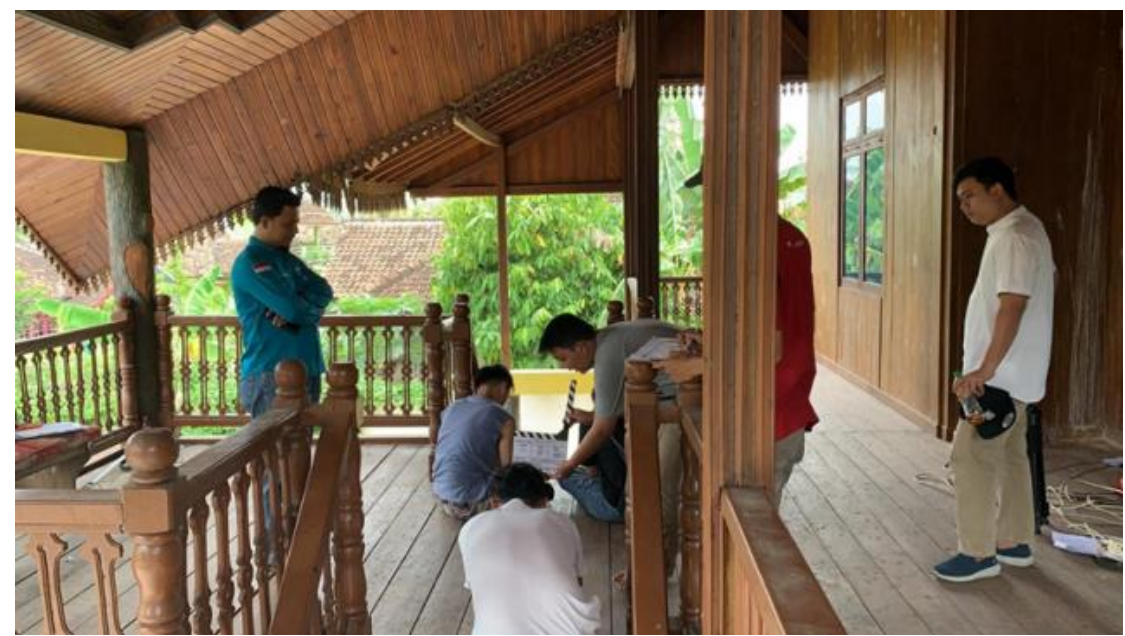

Gambar 2. Proses pendampingan oleh dosen

Setiantono (2015) mengemukakan tahapan-tahapan dalam proses produksi antara lain fase setting up. Tahapan ini memastikan seluruh kru, aktor, dan logistik yang dibutuhkan telah sesuai dengan jadwal produksi hari tersebut. Kedua, tahap rehearsal yakni sutradara memberikan penjelasan mengenai proses produksi yang akan dilakukan pada hari itu kepada seluruh kru dan aktor. Ketiga, fase setting up shots yakni menentukan posisi aktor dan kamera sesuai dengan script dan storyboard yang telah ditentukan. Keempat fase checking the tape, setelah proses shooting dilakukan (take), sutradara melakukan review shot tersebut. Proses take untuk sebuah shot bisa dilakukan berulang kali jika sutradara belum merasa puas akan hasil yang didapatkan.

Proses shooting film membutuhkan banyak hal. Untuk mendapatkan hasil yang maksimal, dibutuhkan unsur-unsur pendukung yang sesuai, mulai dari aktor, kru, lokasi shooting, kamera, lampu, transportasi, konsumsi serta properti yang dibutuhkan. Proses film produksi film Angkon dilakukan di Desa Pampangan, Gedong Tataan Kabupaten Pesawaran. Tempat tersebut dipilih karena terdapat rumah adat Lampung dan latar lainnya yang sesuai isi cerpen.

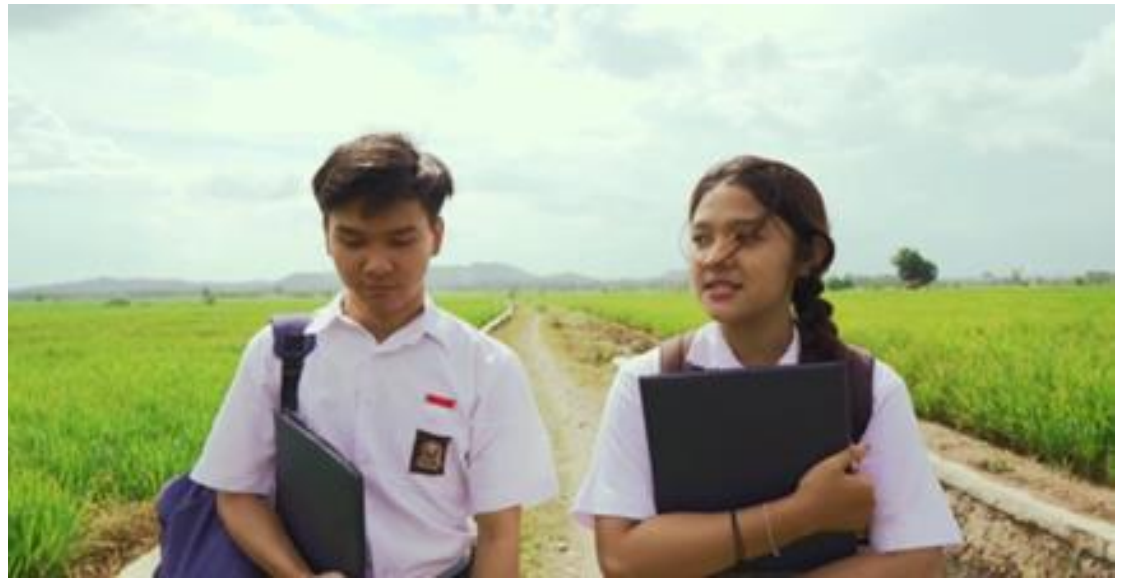

Gambar 3. Proses shooting film pendek 
Tahap terakhir dalam pembuatan film adalah pascaproduksi. Tahap ini mengumpulkan seluruh materi audio dan visual dari keseluruhan proses produksi yang kemudian disatukan menjadi satu film yang utuh. Proses ini dinamakan editing. Proses ini membutuhkan waktu yang cukup lama sekira satu bulan. Dalam hal ini ada 4 pihak yang terlibat yakni peneliti, penulis skenario, sutradara, dan editor. Setelah selesai diedit, proses selanjutnya adalah evaluasi. Evaluasi terhadap film dilakukan dengan cara menonton film bersama lalu meminta respons dari penonton. Respons tersebut menjadi masukan-masukan untuk proses editing lanjutan dan untuk pembuatan episode berikutya. Setelah dianggap cukup, film diunggah ke youtube.

\section{Simpulan}

Proses ekranisasi cerpen Perempuan di Rumah Panggung ke Film Pendek Angkon melahirkan beberapa perbedaan yang cukup signifikan. Perbedaan sudah terlihat dari adanya perubahan judul dari cerpen ke film yang semula berjudul Perempuan di Rumah Panggung menjadi Angkon. Perubahan tersebut disinyalir untuk kepentingan praktis di mana judul Angkon lebih memiliki nilai jual daripada judul sebelumnya. Selain itu pembuat film ingin memberikan porsi lebih atau menegaskan konsep angkon yang terdapat dalam cerpen. Perubahan-perubahan lain terjadi pada unsur tokoh, latar, benda, dan alur.

Selain perubahan terjadi juga pengurangan dan penambahan. Pengurangan terjadi dalam jumlah eposide. Episode cerita cerpen Perempuan di Rumah Panggung terdiri dari 29 episode cerita. Sementara di film Angkon terdapat 26 episode. Ada episode yang tidak ditampilkan dalam film yaitu episode para tokoh saat masa kanak-kanak. Pengurangan lainnya terdapat pada tokohtokoh dalam film. Selain perubahan dan pengurangan, terdapat penambahan variasi. Hal itu terjadi disebabkan adanya kreativitas sutradara saat mengadaptasi cerpen dan film.

Sementara itu proses pembelajaran ekranisasi melalui pembuatan film pendek membutuhkan kerja kolektif dan kolaboratif serta membutuhkan kompetensi khusus di bidang sinematografi. Pembelajaran ekranisasi dapat menjadi alternatif pembelajaran sastra yang menarik. Film dapat merangsang semua aspek pendidikan, seperti kognitif, psikomotor, dan afektif. Mahasiswa merasa lebih tertarik untuk memahami dan mengapresiasi karya sastra. Mahasiswa juga lebih termotivasi dalam menulis skenario dan memproduksi film.

Adapun untuk saran yang diberikan di antaranya:

1. Diperlukan sebuah perencanaan yang matang tentang pembuatan film pendek karena pada kenyataan di lapangan menunjukkan ada kesulitan dalam membentuk tim dan merealisasikan jadwal shooting.

2. Dalam membentuk tim film dibutuhkan keterlibatan orang yang profesional di bidang sinematografi. Hal ini dikarenakan banyaknya kebutuhan akan kru film mulai pra, selama, maupun setelah pembuatan film.

\section{Ucapan Terima Kasih}

Ucapan terima kasih disampaikan kepada Direktorat Riset dan Pengabdian Masyarakat (DRPM) Ristek-BRIN atas hibah yang diberikan melalui skema Peneltian Dosen Pemula tahun 
pelaksanaan 2020.

\section{Daftar Pustaka}

Al Fajri dkk, .2015. Analisis Web Series dalam Format Film Pendek (Studi Kasus Web Series 'Malam Minggu Miko Episode Nissa'. Wimba, ISSN:2085-0948.

Aniskurli, Syifa Dkk, .2020. Ekranisasi Novel Dua Garis Biru Karya Lucia Priandarini ke Bentuk film Dua Garis Biru karya Gina S. Noer dan Implikasinya terhadap Pembelajaran Sastra di SMA. Jurnal Wahana Pendidikan, 7(2), 139-150.

Ardiyanto, DT. 2014. Dari Novel ke Film: Kajian Teori Adaptasi sebagai Pendekatan dalam Penciptaan Film". Jurnal Panggung 16-24.

Damono, Sapardi Djoko. 2005. Pegangan Penelitian Sastra Bandingan. Jakarta : Pusat Bahasa. Eneste, Pamusuk .1997. Novel dan Film. Flores: Nusa Indah.

Estyaji, Dimas. 2017. Ekranisasi Cerpen Filosofi Kopi dalam Kumpulan Cerpen Filosofi Kopi karya Dewi Lestari ke Dalam Film Filosofi Kopi Sutradara Angga Dwimas Sasongko. Skripsi. Yogyakarta: Prodi Bahasa dan Sastra S1, Universitas Negeri Yogyakarta.

Faidah, Citra Nur. 2019. Ekranisasi Sastra sebagai Bentuk Apresiasi Sastra Penikmat Alih Wahana. Jurnal Hasta Wiyata.

Fakhrurozi, Jafar dan Qadhli Jafar Adrian. 2020. Ekranisasi Cerpen ke Film Pendek: Alternatif Pembelajaran Kolaboratif di Perguruan Tinggi. Prosiding Seminar Daring Nasional: Pengembangan Kurikulum Merdeka Belaja. Bengkulu: Universitas Bengkulu.

Istadiyantha dan Rianna Wati. 2015. Ekranisasi Sebagai Wahana Adaptasi dari Karya Sastra ke Film”. Jurnal Haluan Sastra dan Budaya FIB UNS.

Kurniawan, Indra .2017. "Ekranisasi, Transformasi, dan Alih Wahana." Artikel. Padang: Universitas Negeri Padang.

Maghfiroh, dkk .2013. Ekranisasi Cerpen "Jendela Rara" ke Film Rumah Tanpa Jendela: Kajian Psikologi Anak.” Jurnal Publika Budaya Universitas Jember. ISSN: 2338-9923.

Moleong, L. J. 2010. Metodologi Penelitian Kualitatif. Bandung: Remaja Rosda karya.

Nurgiyantoro, Burhan .2018. Teori Pengkajian Fiksi. Yogyakarta: Gajah Mada University Press. Praharwati dkk. 2017. Ekranisasi Sastra: Apresiasi Penikmat Sastra Alih Wahana. Buletin AlTuras, Mimbar Sejarah, Sastra, Budaya, dan Agama, ISSN 0853-1692.

Suseno .2017. Filmisasi Karya Sastra Indonesia: Kajian Ekranisasi pada Cerpen dan Film "Tentang Dia", Artikel. Semarang: Program Studi Bahasa Sastra Indonesia, FBS Universitas Negeri Semarang.

Woodrich, Christopher A. 2017. Ekranisasi Awal: Bringing Novels to The Silver Screen in The Dutch East Indies. Yogyakarta: UGM Press. 